\title{
Post-birth Rituals: Ethics and the Law
}

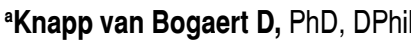 \\ 'Ogunbanjo GA, FCFP(SA), MFamMed, FACRRM, FACTM
}

aSteve Biko Centre for Bioethics, Faculty of Health Sciences, School of Clinical Medicine, University of the Witwatersrand bDepartment of Family Medicine and PHC, Faculty of Health Sciences, University of Limpopo (Medunsa Campus),

Correspondence to: Prof Donna Knapp van Bogaert, e-mail: Donna.VanBogaert@wits.ac.za

\begin{abstract}
Placental rituals and other birth-by rituals are common in various societies. These rituals often include culturally determined behavioural sequences which operate as anxiety-releasing mechanisms and they serve to offer a spiritual means of 'control' over the future health and welfare of mother, child, and even the community. As long as such rituals do not cause harm, they should be respected for the role that they play and be left alone. This article discusses ethical and legal considerations regarding post-birth rituals and its relevance to South Africa with special reference to the South African Human Tissue Act.
\end{abstract}

(P) This article has been peer reviewed. Full text available at www.safpj.co.za

SA Fam Pract 2008;50(2):45-46

\section{Introduction}

Our ancient ancestors looked for explanations of cause and effect in an unscientific world, for example why women bled monthly, without being wounded. In seeking answers, they turned to the natural world seeing the similarity of many ancient cosmologies, between the lunar cycles and the cycles present in a woman's life: waxing (young and nubile); full (middle-aged and reproducing); and waning (old and wise). Moreover, women bleed in a cyclical pattern similar to the cycles of the moon. Menstrual blood became regarded by some as the origin of life and the source of wisdom. ${ }^{1}$ It was also believed that during pregnancy, menstrual blood clotted to form a baby (Aristotle, philosopher and naturalist, believed the same). The sacred feminine was represented by natural phenomena: while a cave represented the womb, mountains represented the breasts, and rivers the uterine fluids - manifesting the creative principle of all life. ${ }^{2}$

\section{Discussion}

Fertility myths and folk tales as well as taboos surrounding the feminine still abound. Taboos are manifestations of the sacred (i.e. that which counters the profane), aimed at providing protection from any threat to the cosmic order, as well as at repairing any disturbance of its order. Taboos are prohibitions or restrictions imposed on certain actions or words by social custom. Taboos set persons or objects apart as sacred, prohibited, or accursed. Moreover, patriarchal societies are often constructed on and maintained by taboos. ${ }^{3}$

'Woman-things' involving fertility myths and traditions are still widespread, and culturally influenced behaviour associated with placenta disposal remains a characteristic of various modern and ancient societies. In many cultures, the placenta and umbilical cord are regarded as holders of great power. ${ }^{4}$ Some myths hold that pieces of placenta were used to create the earth and the sun., ${ }^{2,5}$

New Zealand's indigenous Maoris call the placenta turangawaiwai or whenua, which also means a place or land. The land nourishes the people in the same way that the placenta nourished the baby and, after birth, it is ritually planted with a tree thus establishing a personal, spiritual, symbolic and sacred link between land and child. ${ }^{6}$ Amongst Native American Indian Navajo tribes it is customary to bury a baby's placenta within the Sacred Four Corners of the tribe's reservation thus binding infant to land and ancestors. ${ }^{6}$

In the Kenyan Luo culture, the placenta of a girl must be buried on the left-hand side of her mother's house, while the placenta of a boy must be buried on the right-hand side. ${ }^{7}$ This is because within the Luo cosmological and symbolic system, the left side relates to impermanency and vulnerability, whilst the right signifies permanency and authority. So girls are regarded as impermanent tribal members as they will move outside the family when married, but boys will carry on as patriarchal authorities. ${ }^{7,89}$ In Thai culture, the placenta is salted and placed in a jar before being buried under a tree that corresponds to the symbol of the Asian year of the child's birth. ${ }^{6,7}$

The burial of parts of the birthing matter is a common post-partum ritual in many cultures. In Cambodia, for example, the placenta ("the globe of the origin of the soul") must be buried in a special location designed to protect the baby, the location being fortified with a spiky plant to keep evil spirits from interfering with the baby's good. ${ }^{10}$ In Malaysia, the placenta is considered a baby's other sibling, whereas in Mexico it is viewed as its el compañero (companion). As such, in both cultures due accord is given to its place of burial. Placentas in Korea are given names dependent on the month of their 'birth' before undergoing ritual burial..$^{11}$ In Turkey, if parents wish their child(ren) to be devout, they may bury the placenta in the courtyard of a mosque. ${ }^{12}$ Amongst the Kikuyu in Kenya, the placenta and the umbilical cord are believed to symbolise the attachment of the child to the mother and its roots in the traditional society. As a symbol of fertility, the placenta is deposited in an uncultivated field and covered with grass and grains. ${ }^{13,14}$ Like the Kikuyu, native Hawailans typically plant the placenta in the ground to bind the child to his or her homeland and ancestors. ${ }^{15-17}$ In the Ukraine, traditional midwives divine from the placenta the number of further children a woman might expect to bear. ${ }^{15} \mathrm{In}$ 
Transylvania, if a couple desires not to have any more children, they burn their baby's placenta and mix it with ashes, and to render himself infertile, the husband is obliged to drink this mixture. ${ }^{6,7,70}$

In the Sekhukhune district of Mpumalanga, South Africa, about $10 \%$ of women delivering in hospitals take their placentas and umbilical cords home with them when they are discharged. Pieces of the placenta and of the umbilical cord are selected and left to dry in the sun for the purpose of making muti - the remainder is buried. The muti is then used for two purposes: to stimulate the fertility of infertile women and to ensure congenital love or bonding between siblings. ${ }^{18}$

From such examples, we can see that the placenta and other birth-by rituals are common in various societies. "Placental rituals" here refers to culturally determined behavioural sequences which operate as anxiety-releasing mechanisms; they serve to offer a spiritual means of 'control' over the future health and welfare of mother, child, and even the community. ${ }^{16}$ As long as such rituals do not cause harm, they should be respected for the role that they play and left alone.

\section{The South African Human Tissue Act}

Chapter 2 of the Human Tissue Act states that "human tissue, blood and gametes of living persons can only be used for medical or dental purposes (such as transplantation, or the production of a therapeutic, or prophylactic substance)." The Act further states that "placenta, fetal tissue and umbilical cord, except with the consent of the Minister and subject to any condition mentioned in the consent, shall not be used for any of the purposes referred to earlier, namely the production of a therapeutic or prophylactic substance."19

The Act is thus clear and specific; the traditional practice sans ministerial sanction is incompatible with the law. Yet, opponents of this view claim that to prohibit this traditional practice will result in women opting for home delivery in order to be at liberty to follow their tradition. Thus, so goes the argument, women will be at higher risk of increased morbidity and mortality. ${ }^{20} \mathrm{Hence}$, we face an ethical dilemma: while prohibition of the tradition might harm women at childbirth (as home deliveries constitute a greater risk for women than do skilled-care hospital deliveries), supporting the tradition might harm the community through exposure to a potential source of infectious disease.

\section{Section 9(3) of the Constitution of the Republic of South Africa (Act} 108 of 1996) prohibits unfair discrimination directly or indirectly against anyone on one or more grounds, including culture. Section 31(1a) supports the right to enjoy one's culture. ${ }^{21}$ It raises the question of whether the Human Tissue Act, in this regard, is anti-constitutional. From a medical and ethical point of view, the real question is: Is the practice harmful? While the answer is not clear-cut, it also raises the problem of traditions and traditional medicine. It has been argued that traditional medicine should be submitted to the same rules as Western medicine. ${ }^{22}$ Traditional medicine's weaknesses, so it is argued, are the problems involved in autonomy and informed consent, as well as the lack of rigorous scientific auditing. The main strength, on the other hand, is traditional medicine's holistic approach to illness which involves the next of kin, the community, as well as the ancestors. Overcoming the weaknesses, however, runs the risk of taking away the core of the tradition. ${ }^{23}$ Thus from this perspective, acts of familiar binding are positive acts, and should not be abolished unless there are sufficient good reasons for doing so.

In the context of HIV/AIDS, viral hepatitis, and syphilis affecting a large proportion of pregnant women in South Africa, one could argue that the traditional practice constitutes a public health hazard at least for the family and close community. Therefore, this practice should not be allowed. Yet, to fully understand the level and extent of infection risk, what the rituals entail requires closer examination and a determination of whether, among other issues, the placenta is thoroughly cooked before it is eaten; whether the placenta is sufficiently well-buried to ensure that it does not contaminate the surroundings; what the potential life span of any virus or other potential pathogen involved is, etc.

In many societies the placenta is considered "infectious waste" and is discarded appropriately (or in some cases sold to private companies for research). Yet, in the United States island state of Hawaii, heightened sensitivity to cultural practices resulted in a modification of the law in 2005, which permits women, should they so desire, to take their placentas home. ${ }^{17}$

In the South African context, given the multiplicity of rituals, taboos and traditions involving women and their placentas, reflection of medical, scientific, legal and ethical issues must be carefully unpacked before any sweeping decisions are made. Until then, it would seem that this particular tradition stands in conflict with the law.

References

1. Rings L. Ancient symbols and ideas. New York: Plentium Press. 1999

2. Ashley M. The book of myths and legends. Bristol: Paragon. 2000

3. Rolston III, H. Genes, genesis, and God: Values and their origins in natural and human history. Cambridge: Cambridge University Press. 1999:311.

4. Morford MPO, Lenardon RJ. Classical mythology. 5th ed. White Plains, New York: Longman. 1995.

5. Adamson PB. Some rituals associated with parturition in antiquity. Folklore 1985;96(2):176-83.

6. Guthrie P. Many cultures revere placenta, by-product of childbirth. Cox News Service. 1999:. http://www.tidesoflife.com/placenta.htm (Accessed 06/2007).

7. Kibiti RN. Culture and gender. Mila 1996;(1):60-73.

8. Nangendo SM. The tradition of Ramogi: beliefs and practices of the levirate amongst the Luo in Bondo Division, Bondo District, Western Kenya. Mila 2005;(6):23-32.

9. Mulemi BA, Nangendo SM. Therapeutic strategies and traditional medical knowledge of the people of Bar Chando Sub-location Bondo District, Kenya. Curare 2001;(24): 47-56.

10. Kawango EA. Ethnomedicine remedies and therapies in maternal and child health among the rural Luo. In: I. Sindiga, N. Chacha, and MP Kanunah (Eds). Traditional medicine in Africa. Nairobi East African Educational Publishers, 995:80-93.

11. Sich D. Traditional concepts and customs on pregnancy, birth and postpartum period in rural Korea. Social Science and Medicine. 1981;15:65-9.

12. Tortello R. A time to live: Jamaican Birth Rituals. 2000:. http://www.jamaica-gleaner.com/pages/history/story0079.html (Accessed 06/2007).

13. Mbiti JS. African religions and philosophy. Nairobi. East African Educational Publishers. 1969.

14. Finke J. Traditional music and cultures of Kenya: Kikuyu - Society (Mbari ya Mumbi): http://www.bluegecko.org/kenya/tribes/kikuyu/society.htm (Accessed 04/2007).

15. Khushi A. The placenta and cord in other cultures. In: S Rachana (Ed). Lotus Birth. Yarra Glen, Australia: Greenwood Press. 2000:53-60.

16. Davidson JR. The shadow of life: psychosocial explanations for placenta. Journal of Culture, Medicine and Psychiatry 1985;9(1):75-92.

17. Cook LN. Hawaiian law wow permits parents to keep placentas. 2006: http:// www.womensenews.org/article.cfm/dyn/aid/2841/context/archive (Accessed 04/2007).

18. Ramara P. (advanced midwife). Personal communication.

19. Human Tissue Act № 65 of 1983, Human Tissue Act Amendment № 66 of 1984, Human Tissue Act Amendment № 51 of 1980. Pretoria. Government printer.

20. Shah IH, Say L. Maternal mortality and maternity care from 1990 to 2005. Reproductive Health Matters 2007;15(30):27.

21. Constitution of the Republic of South Africa. 1996.

22. Nyika A. Ethical and regulatory issues surrounding African traditional medicine in the context of HIV/AIDS. Developing World Bioethics 2007;1:25-34.

23. Knapp van Bogaert D. Ethical considerations in African traditional medicine: a response to Nyika. Developing World Bioethics 2007;7:35-40. 